\title{
6.17 Філософсько-педагогічні аспекти підготовки військових льотчиків
}

Підготовка майбутніх військових льотчиків до виконання бойових польотів, як будь-яке педагогічне і психологічне явище, є складно організованим і багатоаспектним утворенням. Тому важливо досліджувати існуючі в науці підходи й погляди, що розкривають його сутність. Аналіз основних наукових джерел свідчить, що на сучасному етапі ще не сформована остаточна теорія підготовки майбутніх військових льотчиків до бойових польотів, хоча окремі іiі аспекти досліджувалися й продовжують вивчатися.

Підготовка майбутніх льотчиків до бойових польотів у контексті більш загальної проблематики професійної підготовки літного складу історично розбудовувалося переважно в області психологічної науки. Наприклад, у професійній психопедагогиці [510], теорії авіаційної психології віддається безумовно вихідна позиція, що домінує, залишаючи педагогічній складовій другорядне місце. Остання ідентифікується тільки в якості методик навчання, що безпосередньо випливають зі спеціальної психологічної теорії, насамперед, в області авіаційної психології (наведена автором методика індивідуальноорієнтованого аналізу авіаційної події у формі рольової гри заснована на психологічній теорії міжособистісних конфліктів).

На нашу думку, звуження ролі педагогічної складової у теорії професійної підготовки майбутніх льотчиків до винятково технічного (техніко-методичному) елементу не зовсім правомірно. Професійна підготовка майбутніх льотчиків до виконання бойових польотів $є$ частиною більш широкого освітнього процесу, що відбувається в певному освітньому середовищі, при певних психологопедагогічних умовах і закономірностях і має цілий комплекс педагогічних особливостей і властивостей. Философсько-педагогічні основи тут не менш важливі, ніж теоретико-психологічні. Як відзначає Р. Н. Макаров, «тільки на основі системного підходу можуть бути об'єднані численні області психології, а також знайдена загальна мова між педагогікою, філософією навчання й суміжними дисциплінами» [511]. 
Бреславец М. М., Кремешний О.I., Маренич С.Ю. розглядають підготовку майбутніх військових льотчиків із класичних педагогічних позицій - як комбінацію теорії і практики надання знань, умінь і навичок для виконання функціональних обов'язків у конкретних обставинах на певний строк (для підготовки військового льотчика необхідно додати - при наявності відповідних льотних здібностей, фізичних і психофізіологічних якостей) [512-514]. При цьому, конкретний зміст теорії підготовки літних екіпажів військової авіації вчені бачать у визначенні «необхідного утвору ... для оволодіння спеціальністю військового льотчика», розробці відповідних методик на всіх етапах підготовки, а також розробці керівних і організаційно-методичних документів, у тому числі, для різних типів літаків. Під об’єктом даної теорії розуміється льотчик (льотний екіпаж), під предметом - функціонування системи його (ix) підготовки. Практика ж підготовки - «льотна підготовка» - повинна, на думку авторів, безпосередньо надавати й формувати у курсантів систему професійних знань, умінь і навичок, а також психологічну готовність до виконання бойових польотів.

Структуру підготовки льотних екіпажів військової авіації вищевказані дослідники представили в кілька етапів:

- $\quad$ відбір льотного складу (попередній - при вступі до авіаційне ВВНЗ, що здійснюється - в умовах льотної підготовки);

- початкова підготовка льотного складу (первинна (по суті пропедевтична) - навчання техніці пілотування й «уведенню» у професію) i базова - комбінація досвіду первинної підготовки з освоєнням бойового літака;

- основна підготовка льотного складу і удосконалювання бойової виучки (здійснюється на бойових літаках у військових частинах);

- $\quad$ перенавчання льотного складу на нову для них авіаційну техніку (теоретичне - у спеціалізованому центрі бойової підготовки авіаційних фахівців і практичне - там же або у військових частинах).

Дозволимо собі наголосити, що елемент запропонованої ними структури підготовки льотного складу військової авіації - етап основної підготовки літного складу - розкритий досить традиційно й схематично. Фактично, це набір добре 
відомих фахівцям галузі організаційно-методологічних установок і методик навчання, де недостатньо фундаментальної теоретико-педагогічної основи (філософії навчання), комплексної системи педагогічного моделювання умов, закономірностей і принципів підготовки майбутніх військових льотчиків. Хоча крок у цьому напрямку безумовно здійснений - запропоноване адаптоване до військового льотного середовища бачення теорії й практики підготовки. До того ж, автори висловлюють зручну, за нашим переконанням, думку про необхідність підготовки військових льотчиків паралельно з одержанням ними вищої освіти (фактично за зразком наземних військових фахівців) і переходу на послідовну підготовку за моделлю «спочатку вища освіта (у військових ВНЗ) - потім льотна підготовка (у спеціалізованих установах)» [512], що буде сприяти «зануренню» курсантів-льотчиків у льотне середовище й додасть методологічної зв'язаності всім етапам підготовки.

Тому, підготовку майбутніх військових льотчиків ми будемо розуміти як спеціально організований процес навчання і виховання в умовах військового закладу вищої освіти, що має науково-педагогічну, організаційно-методичну й тактико-технічну специфіку та результатом якого $є$ їхня готовність до професійної військової діяльності внаслідок формування системи знань, умінь і навичок виконання бойових завдань у повітрі як мистецтва підготовки й виконання бойових польотів.

Деякі науковці ототожнюють професійну підготовку за професійною компетенцією, розуміючи під нею, відносно курсантів військових ВВНЗ, «інтегральну характеристику, що визначає його (курсанта) здатність як військового фахівця вирішувати професійні проблеми й типові професійні завдання, що виникають у реальних ситуаціях навчальної й бойової діяльності, використовуючи знання, професійний і життєвий досвід, цінності й нахили» [515]. У якості компонентів ії структури вчений висуває професійний досвід, системне сприйняття професійної реальності, вільне орієнтування в предметній області, технологічність, здатність інтегруватися з іншим досвідом, креативність i здатність до рефлексії. По суті, він зводить професійну підготовку до 
індивідуального, надбаного під час навчальної і навчально-професійної діяльності.

Інші, [516, 517] розглядають професійну підготовку курсантів-льотчиків як окрему філософсько-педагогічну категорію в трьох площинах (аспектах):

1) 3 боку суб'єктів керування - це процес створення державними інститутами, суб'єктами керування умов для цілеспрямованого формування й розвитку у курсантів-льотчиків певних можливостей для майбутньої професійної діяльності; 2) з боку курсантів - це процес досягнення необхідного рівня підготовленості до професійної діяльності за призначенням (компетенціями) і 3) як результат професійної підготовки. Така позиція, у цілому, корелює із тлумаченнями професійної підготовки, якої дотримуються в більшості енциклопедичних і словникових виданнях 3 педагогиці і більше імпонує нам, тому надалі ми будемо використовувати іiі як базову.

Проаналізовані джерела 3 питань розуміння професійної підготовки, об'єктивно відсилають нас до двох ключових моментів - процесу формування професійно значимих знань, умінь і навичок майбутнього фахівця в ході освітньої діяльності (професійної освіти) і результату цієї діяльності, який можна представити у вигляді сформованих професійних компетенцій з обов'язковим включенням психологічної готовності до майбутньої професії. У свою чергу, це вказує на те, що професійна підготовка є формою й інструментом реалізації професійної освіти: саме в ії ході відбувається ідентифікація дидактичних цілей, постановка педагогічних завдань, моделювання навчання, уточнюються, конкретизуються й корелюються методи і способи навчання, формується педагогічний результат. У той же час професійна підготовка сама може виступати індикатором успішності підготовки і готовності до професійної діяльності.

Виходячи з вище викладеного, під професійною підготовкою майбутніх льотчиків будемо розуміти дидактичну систему організаційно-освітніх i конкретно-методичних заходів, метою якої $є$ навчання і виховання особистості військового льотчика, здатного до виконання всього комплексу бойових завдань 
і конкретним результатом якої є його професійна й психологічна готовність до успішної професійної діяльності.

Тобто, професійна готовність майбутнього льотчика являє собою багатогранне явище, що включає не тільки знання про літальний апарат, техніку пілотування, навколишнє середовище, але й про льотчика, його можливості та обмеження, прийоми управління власним станом та ін. Причому значимість знань льотчика про себе у забезпеченні безпеки польотів не менш, чим значимість його знань про техніку пілотування та експлуатацію систем літака.

Поняття «професійна підготовка» $\mathrm{i}$ «підготовка за фахом» у вітчизняній науковій літературі досить часто ототожнюються [518]. Ми пропонуємо розуміти надалі професійну підготовку майбутніх льотчиків як комплекс спеціальних, спеціально-тактичних навчальних дисциплін і курсів, а також спеціалізованого тренажерного, фізичного й фізіологічного навчання, які становлять базовий компонент професійної підготовки військових льотчиків у ВВНЗ і спрямований на формування у них спеціальних військових льотних компетенцій й професійної готовності до виконання бойового польоту.

Якість в освітньому процесі є фундаментальною й інтернаціональною категорією, оскільки становить сутність їі мети.

У Національній доктрині розвитку освіти визначено, що «якість освіти $є$ національним пріоритетом i передумовою національної безпеки держави, дотримання міжнародних норм і вимог законодавства України щодо реалізації права громадян на освіту ... якість освіти визначається на основі державних стандартів освіти й оцінки громадськістю освітніх послуг».

За визначенням Міністерства освіти й науки України якість освіти - це комплекс характеристик освітнього процесу, що визначають послідовне і практично ефективне формування компетентності й професійної свідомості; певний рівень знань і вмінь, розумового, фізичного й морального розвитку, якого досягли випускники освітньої установи відповідно до запланованих цілей навчання й виховання. 
У сучасному розумінні якість освіти - це не лише характеристика суми знань, засвоєних людиною. У світі, де знання і технології оновлюються швидше, ніж життя одного покоління людей, слід спрямувати навчальний процес не тільки на засвоєння базових знань, а й на набуття потреби, умінь і навичок самостійно засвоювати нові знання та інформацію протягом усього життя й ефективно використовувати їх на практиці, вміння сприймати зміни, які стають невід’ємною рисою буття людини, готовності вчасно відмовитися від старого досвіду й норм поведінки. На думку В. Вікторова, особливої ваги у XXI ст. набуває і такий критерій якості освіти, як ступінь ії адекватності природним здібностям кожної людини, особистісно-орієнтований характер освіти [519]. Максимальне наближення освіти й виховання до розкриття природних здібностей кожної людини - мета педагогіки.

Якість вищої професійної освіти, характеризується такими складовими:

- по-перше, якістю навчально-методичної бази, що передбачає ресурсне забезпечення закладів освіти на належному рівні, залучення до навчального процесу не тільки таких якісних, традиційних компонентів, як підручники, а й нових сучасних засобів і методів пізнання, пов'язаних із сучасними технічними можливостями;

- по-друге, якістю педагогічних кадрів та професорсько-викладацького складу [520];

- по-третє, якістю об’єкта навчання - це рівень підготовки фахівців, здатних до ефективної професійної діяльності, до швидкої адаптації в умовах науково-технічного прогресу, які володіють технологіями в межах свого фаху, вмінням вик

У широкому сенсі якість освіти розуміється як збалансована відповідність процесу, результату і самої освітньої системи меті, потребам і соціальним нормам (стандартам) освіти; у вузькому розумінні - перелік вимог до особистості, освітнього середовища й системи освіти, яка реалізує їх на певних етапах навчання людини, якому відповідає певна сукупність показників. застосовувати свої знання при вирішенні професійних завдань. 
Отже, якість професійної підготовки майбутніх льотчиків слід розглядати як інтегрований показник відповідності придбаних ними професійних компетенцій, професійно значимих умінь і навичок, а також реальної готовності до виконання бойових завдань відносно конкретних вимог, запитів і очікувань суспільства до сучасних кадрових офіцерів-льотчиків.

Бойові польоти - це основа професійної діяльності військового льотчика, головний iї компонент, у якому він демонструє свій рівень професійної підготовки, фізичну й психологічну підготовленість, здатність до вдосконалювання й моральну витримку. Не будучи психолого-педагогічною категорією, як такою, бойовий політ стає додатковим об'єктом теорії авіаційної психології й педагогіки з проблеми професійної підготовки майбутніх льотчиків.

Підготовка майбутніх льотчиків до бойових польотів являє собою найважливішу за значенням частину їх професійної підготовки, оскільки їх основна професійна діяльність по призначенню - бойові (спеціальні бойові) польоти. Стрімкий технічний розвиток сучасних літальних апаратів, поява нових видів озброєння, навігаційного обладнання, систем наведення і вогню, нові бойові завдання і прийоми ведення повітряних боїв суттєво актуалізують звертання до даної проблематики.

Тому, пропонуємо розглядати бойовий політ як основний вид професійної діяльності військових льотчиків, спрямований на виконання бойового завдання, а готовність до нього (фізична, психологічна, технічна) - як ключовий компетентностний індикатор педагогічної системи забезпечення якості підготовки майбутніх льотчиків до виконання бойових завдань (польотів).

А до структури готовності випускника-льотчика до професійної діяльності після закінчення ВВНЗ включити наступні компоненти: мотиваційний позитивне відношення до професії, інтерес до неї); орієнтовний (уявлення про особливості та умови професійної діяльності, про її вимоги до особистості); операційний (володіння способами та прийомами професійної діяльності, необхідними знаннями, вміннями, навиками); вольовий (самоконтроль, вміння управляти собою під час виконання службових обов'язків); оціночний (самооцінка своєї 
професійної підготовленості). Високий рівень розвитку цих компонентів показник професійної готовності випускника до виконання поставлених завдань [521].

Таким чином, якісна професійна підготовка до бойових польотів майбутніх льотчиків - це комплекс спеціальних, спеціально-тактичних навчальних дисциплін і курсів, а також спеціалізованого тренажерного, фізичного й фізіологічного навчання, які забезпечують відповідний рівень підготовки й готовності курсантів-льотчиків ВВНЗ до ефективного виконання бойових завдань у відповідності з реальними вимогами ведення сучасної війни та запитів суспільства. Істотною складової цієї підготовки є наземне навчання бойовим польотам. При підготовці майбутніх військових льотчиків їх теоретичні компетенції здобуваються в навчальному закладі й уписуються в єдину ідеологію бойової підготовки літного складу авіації Збройних Сил. 